\title{
Analisis Risiko Rantai Pasok Beton Ready Mix pada Proyek Pembangunan Apartemen di Surabaya
}

\author{
Cahyono Bintang Nurcahyo, I Putu Artama Wiguna \\ Jurusan Teknik Sipil - Fakultas Teknik Sipil dan Perencanaan \\ Institut Teknologi Sepuluh Nopember (ITS) \\ Email: bintang@ce.its.ac.id
}

\begin{abstract}
This paper presents Risk Analysis of Ready Mix Concrete Supply Chain at apartment building in Surabaya. The first process is Identify Risks to determine risk variables which may affect the supply chain activity in project. The second process is to perform Risk Assesment by assessing risk probability of occurrence and degree of impact. The last process is Plan Risk Responses which aim to develop management actions in order to enhance opportunities and to reduce threats to project objectives.

There are 26 risk variables which classified as material flow, financial flow, and information flow. Both of contractor and supplier tend to choose preventive and curative responses to reduce threats to project objetives

Keywords: Risk Analysis, Supply Chain, Ready Mix, Apartment, Surabaya
\end{abstract}

Abstrak

Makalah ini menyajikan analisis risiko rantai pasok beton ready mix pada proyek pembangunan apatemen di Surabaya. Tahap pertama dilakukan identifikasi risiko untuk menentukan variabel yang berpengaruh pada kegiatan rantai pasok di suatu proyek. Tahap kedua dilakukan penilaian risiko melalui matriks probabilitas $\&$ dampak. Tahap terakhir adalah merencanakan respon risiko yang bertujuan untuk mengembangkan tindakan manajemen guna meningkatkan peluang dan mengurangi ancaman terhadap tujuan proyek.

Berdasarkan hasil survei pendahuluan, diperoleh 26 variabel risiko yang terbagi dalam 3 aliran yaitu aliran material/fisik, aliran finansial, dan aliran informasi. Dari hasil analisis data diketahui bahwa pihak kontraktor maupun pemasok beton ready mix memilih opsi respon risiko dengan upaya mengurangi risiko baik secara preventif ataupun kuratif, sehingga risiko tersebut tidak mengganggu dan menyebabkan dampak yang besar terhadap tujuan proyek.

Kata kunci: Analisis Risiko, Rantai Pasok, Ready Mix, Apartemen, Surabaya

\section{Pendahuluan}

Semakin ketatnya kompetisi antar perusahaan penyedia jasa konstruksi dalam maraknya kegiatan pembangunan apartemen di Surabaya, menyebabkan dibutuhkannya strategi untuk menghasilkan produk yang berkualitas dengan harga yang kompetitif melalui penerapan manajemen rantai pasok.

Secara umum, rantai pasok adalah suatu sistem tempat organisasi penyedia barang/jasa untuk menyalurkan barang produksi dan jasa kepada pengguna jasa. Penerapan strategi rantai pasok pada proyek konstruksi dapat memunculkan risiko dua arah dalam hubungan kerja sama, yang timbul dalam berbagai bentuk dari setiap kegiatan atau aktivitas proyek konstruksi. Pengelolaan risiko yang baik dapat meminimalisir kejadian negatif yang tidak diinginkan, sehingga dapat meningkatkan kinerja perusahaan. Penerapan manajemen rantai pasok dan manajemen risiko diharapkan dapat meminimalisir hambatan yang terjadi pada penyaluran material dari pemasok beton ready mix kepada kontraktor, sehingga dapat menghasilkan produk konstruksi dengan harga bersaing, tepat waktu, dan berkualitas. 


\section{Metodologi}

\subsection{Langkah Penelitian}

Penelitian dimulai dengan penyusunan latar belakang, rumusan masalah dan tujuan penelitian, yang kemudian dilanjutkan dengan studi pustaka untuk mendapatkan variabel risiko pada rantai pasok di proyek konstruksi.

Survei pendahuluan dilakukan untuk mengetahui relevansi variabel risiko dari studi pustaka tersebut terhadap obyek penelitian, sekaligus untuk mendapatkan variabel tambahan dari responden.

Survei utama dilakukan untuk mengetahui persepsi kualitatif responden terhadap variabel risiko, yang kemudian dianalisis untuk mendapatkan risiko yang signifikan.

Survei respon risiko dilakukan untuk mengetahui penyebab, dampak, dan strategi pengelolaan terhadap risiko yang signifikan, yang dilanjutkan dengan penyusunan kesimpulan dan saran.

Detil tahapan penelitian dapat dilihat pada Gambar 1.

\subsection{Data Penelitian}

Terdapat dua jenis data yang digunakan dalam penelitian ini, yaitu:

1. Data Primer, merupakan data yang didapatkan dari penyebaran kuesioner dan wawancara kepada responden dari pihak kontraktor dan pemasok beton ready mix.

2. Data Sekunder dalam penelitian ini adalah:

a. Data umum proyek pembangunan apartemen di Surabaya yang berada dalam fase konstruksi.

b. Data umum perusahaan dan identitas responden dari pihak kontraktor pelaksana.

c. Data umum perusahaan dan identitas responden dari pihak pemasok beton ready mix.

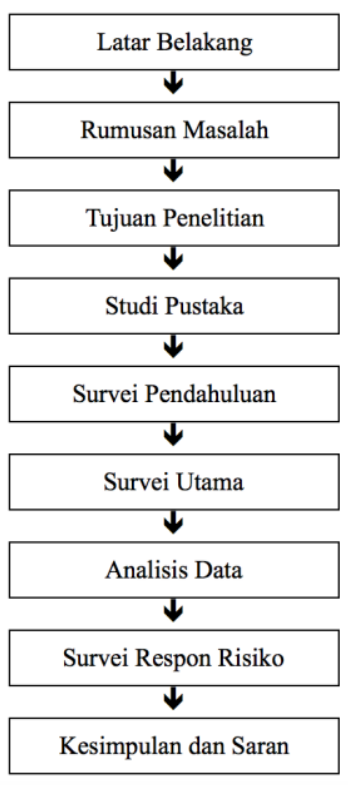

Gambar 1. Diagram Alir Penelitian

\subsection{Variabel Penelitian}

Risiko dalam aktivitas rantai pasok pada proyek pembangunan apartemen di Surabaya dalam penelitian ini adalah risiko pada hubungan kerja sama antara kontraktor dan pemasok beton ready mix. Identifikasi, analisis, dan respon risiko dilakukan dari sudut pandang kontraktor dan dari sudut pandang pemasok, terhadap aktivitas rantai pasok beton ready mix.

Variabel risiko dikelompokkan menjadi aliran material/fisik, aliran finansial, dan aliran informasi, yang secara detil dapat dilihat pada Tabel 1 dan Tabel 2.

Tabel 1. Variabel Risiko Rantai Pasok pada Hubungan Kerja Kontraktor terhadap Pemasok Beton Ready Mix

\begin{tabular}{cl}
\hline \multicolumn{1}{c}{ Aliran Material / Fisik } \\
\hline A1 & $\begin{array}{l}\text { Perizinan pengadaan material khusus yang } \\
\text { berbelit [7] }\end{array}$ \\
\hline A2 & $\begin{array}{l}\text { Pembatasan impor material dan peralatan } \\
\text { pendukung produksi [7] }\end{array}$ \\
\hline A3 & $\begin{array}{l}\text { Ketidakstabilan pasokan material oleh } \\
\text { pemasok kepada kontraktor [7] }\end{array}$ \\
\hline A4 & $\begin{array}{l}\text { Keterlambatan pengiriman material oleh } \\
\text { pemasok kepada kontraktor yang diakibatkan } \\
\text { oleh proses mendapatkan material pengganti } \\
\text { [7] }\end{array}$ \\
\hline A5 & $\begin{array}{l}\text { Ketidaksesuaian kuantitas material yang } \\
\text { dikirimkan oleh pemasok terhadap kuantitas } \\
\text { material yang diminta oleh kontraktor [6] }\end{array}$ \\
\hline
\end{tabular}



ISSN.1907-753X

\begin{tabular}{|c|c|}
\hline A6 & $\begin{array}{l}\text { Ketidaksesuaian kualitas material yang dikirim } \\
\text { pemasok kepada kontraktor, terhadap standar } \\
\text { mutu sesuai spesifikasi pada kontrak [1] [6] }\end{array}$ \\
\hline A7 & $\begin{array}{l}\text { Persyaratan ketat yang berlaku di sekitar } \\
\text { lingkungan proyek terkait pengiriman material } \\
\text { oleh pemasok kepada kontraktor ke lokasi } \\
\text { proyek [7] }\end{array}$ \\
\hline A8 & $\begin{array}{l}\text { Kegagalan pengiriman material oleh pemasok } \\
\text { kepada kontraktor karena lokasi proyek yang } \\
\text { kurang jelas atau sulit dilalui [6] }\end{array}$ \\
\hline \multicolumn{2}{|r|}{ Aliran Finansial } \\
\hline B1 & $\begin{array}{l}\text { Pembayaran yang terlambat atau bahkan tidak } \\
\text { terbayarnya pemasok karena keuangan } \\
\text { kontraktor yang bermasalah [7] }\end{array}$ \\
\hline B2 & $\begin{array}{l}\text { Harga yang kurang kompetitif dari pemasok } \\
\text { kepada kontraktor [7] }\end{array}$ \\
\hline B3 & Kesalahan dalam estimasi biaya [2] \\
\hline B4 & $\begin{array}{l}\text { Frekuensi pembayaran yang dilakukan oleh } \\
\text { kontraktor kepada pemasok [6] }\end{array}$ \\
\hline B5 & Perubahan harga material yang dipasok [6] [7] \\
\hline B6 & Fluktuasi kurs mata uang [7] \\
\hline B7 & $\begin{array}{l}\text { Terjadi peningkatan tarif pajak barang atau } \\
\text { jasa [7] }\end{array}$ \\
\hline B8 & Terjadinya krisis ekonomi [2] \\
\hline \multicolumn{2}{|r|}{ Aliran Informasi } \\
\hline $\mathrm{C} 1$ & $\begin{array}{l}\text { Ketidakjelasan pemasok dalam memberikan } \\
\text { informasi [7] }\end{array}$ \\
\hline $\mathrm{C} 2$ & $\begin{array}{l}\text { Minimnya kepercayaan kontraktor terhadap } \\
\text { pemasok [7] }\end{array}$ \\
\hline C3 & $\begin{array}{l}\text { Minimnya sumber daya peralatan dan/atau } \\
\text { manusia yang dimiliki perusahaan pada proses } \\
\text { pertukaran informasi [7] }\end{array}$ \\
\hline $\mathrm{C} 4$ & $\begin{array}{l}\text { Perubahan spesifikasi dari material yang telah } \\
\text { dipesan kontraktor kepada pemasok [3] }\end{array}$ \\
\hline C5 & $\begin{array}{l}\text { Pengajuan klaim oleh kontraktor terkait } \\
\text { ketidakpuasan material yang dikirim pemasok } \\
\text { [3] }\end{array}$ \\
\hline C6 & Manipulasi informasi oleh pemasok [7] \\
\hline C7 & $\begin{array}{l}\text { Negosiasi tidak berjalan lancar dengan pihak } \\
\text { pemasok [2] }\end{array}$ \\
\hline $\mathrm{C} 8$ & $\begin{array}{l}\text { Tidak adanya petunjuk penggunaan peralatan } \\
\text { dan material oleh pemasok kepada kontraktor } \\
{[2]}\end{array}$ \\
\hline C9 & $\begin{array}{l}\text { Kurang baiknya proses pengawasan dokumen } \\
\text { pengadaan [2] }\end{array}$ \\
\hline $\mathrm{C} 10$ & $\begin{array}{l}\text { Minimnya frekuensi rapat koordinasi antara } \\
\text { pihak yang terlibat dalam proses konstruksi [6] }\end{array}$ \\
\hline
\end{tabular}

Tabel 2. Variabel Risiko Rantai Pasok pada Hubungan Kerja Pemasok Beton Ready Mix terhadap Kontraktor

\begin{tabular}{cl}
\hline \multicolumn{1}{c}{ Aliran Material / Fisik } \\
\hline D1 & $\begin{array}{l}\text { Perizinan pengadaan material khusus yang } \\
\text { berbelit [7] }\end{array}$ \\
\hline D2 & $\begin{array}{l}\text { Pembatasan impor material dan peralatan } \\
\text { pendukung produksi [7] }\end{array}$ \\
\hline D3 & $\begin{array}{l}\text { Ketidakstabilan pasokan material oleh } \\
\text { pemasok kepada kontraktor [7] }\end{array}$ \\
\hline D4 & $\begin{array}{l}\text { Keterlambatan pengiriman material oleh } \\
\text { pemasok kepada kontraktor yang diakibatkan } \\
\text { oleh proses mendapatkan material pengganti } \\
\text { [7] }\end{array}$ \\
\hline D5 & $\begin{array}{l}\text { Ketidaksesuaian kuantitas material yang } \\
\text { dikirimkan oleh pemasok terhadap kuantitas } \\
\text { material yang diminta oleh kontraktor [6] }\end{array}$ \\
\hline
\end{tabular}

\begin{tabular}{|c|c|}
\hline D6 & $\begin{array}{l}\text { Ketidaksesuaian kualitas material yang dikirim } \\
\text { pemasok kepada kontraktor, terhadap standar } \\
\text { mutu sesuai spesifikasi pada kontrak [1] [6] }\end{array}$ \\
\hline D7 & $\begin{array}{l}\text { Persyaratan ketat yang berlaku di sekitar } \\
\text { lingkungan proyek terkait pengiriman material } \\
\text { oleh pemasok kepada kontraktor ke lokasi } \\
\text { proyek [7] }\end{array}$ \\
\hline D8 & $\begin{array}{l}\text { Kegagalan pengiriman material oleh pemasok } \\
\text { kepada kontraktor karena lokasi proyek yang } \\
\text { kurang jelas atau sulit dilalui [6] }\end{array}$ \\
\hline \multicolumn{2}{|r|}{ Aliran Finansial } \\
\hline E1 & $\begin{array}{l}\text { Pembayaran yang terlambat atau bahkan tidak } \\
\text { terbayarnya pemasok karena keuangan } \\
\text { kontraktor yang bermasalah [7] }\end{array}$ \\
\hline E2 & $\begin{array}{l}\text { Harga yang kurang kompetitif dari pemasok } \\
\text { kepada kontraktor [7] }\end{array}$ \\
\hline E3 & Kesalahan dalam estimasi biaya [2] \\
\hline E4 & $\begin{array}{l}\text { Frekuensi pembayaran yang dilakukan oleh } \\
\text { kontraktor kepada pemasok [6] }\end{array}$ \\
\hline E5 & Perubahan harga material yang dipasok [6] [7] \\
\hline E6 & Fluktuasi kurs mata uang [7] \\
\hline E7 & $\begin{array}{l}\text { Terjadi peningkatan tarif pajak barang atau } \\
\text { jasa [7] }\end{array}$ \\
\hline E8 & Terjadinya krisis ekonomi [2] \\
\hline \multicolumn{2}{|r|}{ Aliran Informasi } \\
\hline $\mathrm{F} 1$ & $\begin{array}{l}\text { Ketidakjelasan kontraktor dalam memberikan } \\
\text { informasi [7] }\end{array}$ \\
\hline $\mathrm{F} 2$ & $\begin{array}{l}\text { Minimnya kepercayaan pemasok terhadap } \\
\text { kontraktor [7] }\end{array}$ \\
\hline F3 & $\begin{array}{l}\text { Minimnya sumber daya peralatan dan/atau } \\
\text { manusia yang dimiliki perusahaan pada proses } \\
\text { pertukaran informasi [7] }\end{array}$ \\
\hline $\mathrm{F} 4$ & $\begin{array}{l}\text { Perubahan spesifikasi dari material yang telah } \\
\text { dipesan kontraktor kepada pemasok [3] }\end{array}$ \\
\hline F5 & $\begin{array}{l}\text { Pengajuan klaim oleh kontraktor terkait } \\
\text { ketidakpuasan material yang dikirim pemasok } \\
{[3]}\end{array}$ \\
\hline F6 & Manipulasi informasi oleh kontraktor [7] \\
\hline F7 & $\begin{array}{l}\text { Negosiasi tidak berjalan lancar dengan pihak } \\
\text { kontraktor [2] }\end{array}$ \\
\hline F8 & $\begin{array}{l}\text { Tidak adanya petunjuk penggunaan peralatan } \\
\text { dan material oleh pemasok kepada kontraktor } \\
\text { [2] }\end{array}$ \\
\hline F9 & $\begin{array}{l}\text { Kurang baiknya proses pengawasan dokumen } \\
\text { pengadaan [2] }\end{array}$ \\
\hline F10 & $\begin{array}{l}\text { Minimnya frekuensi rapat koordinasi antara } \\
\text { pihak yang terlibat dalam proses konstruksi [6] }\end{array}$ \\
\hline
\end{tabular}

\subsection{Obyek Penelitian}

Obyek dalam penelitian ini adalah proyek pembangunan apartemen yang sedang dalam fase konstruksi di wilayah Surabaya, yaitu:

1. Pembangunan Apartemen De Papilio, di Jalan Ahmad Yani, Surabaya.

2. Pembangunan Apartemen Bale Hinggil, di Jalan MERR II-C, Surabaya.

3. Pembangunan Apartemen Puncak Bukit Golf, di Jalan Darmo Boulevard, Surabaya. 
4. Pembangunan Apartemen Educity, di Pakuwon City, Surabaya.

5. Pembangunan Apartemen One Icon (Tunjungan Plasa 6), di Jalan Embong Malang, Surabaya.

\subsection{Responden Penelitian}

Survei diartikan sebagai teknik riset dengan memberi batas yang jelas atas data; penyelidikan; peninjauan. Survei ditujukan kepada responden yang memiliki pemahaman detil dan menyeluruh terkait kondisi riil proyek.

Responden dari pihak kontraktor adalah sebagai berikut:

1. Pimpinan Pelaksana Proyek

2. Site Manager

3. Staf Logistik, Pengadaan, Quantity Surveyor, Quality Control

Sedangkan responden dari pihak pemasok beton ready mix adalah sebagai berikut:

1. Kepala Batching Plant

2. Quality Control, dsb.

\subsection{Instrumen Penelitian}

Instrumen penelitian yang digunakan adalah kuesioner, dengan skala persepsi kualitatif berupa rentang skala 1 hingga skala 5.

Skala persepsi kualitatif probabilitas terjadinya risiko adalah:

$1=$ sangat jarang terjadi

$2=$ jarang terjadi

3 = kadang-kadang terjadi

$4=$ sering terjadi

5 = sangat sering terjadi

Skala persepsi kualitatif dampak yang ditimbulkan oleh risiko adalah:

1 = berdampak sangat kecil

2 = berdampak kecil

3 = berdampak sedang

4 = berdampak besar

5 = berdampak sangat besar

\section{Hasil dan Pembahasan}

\subsection{Hasil Survei Pendahuluan}

Survei pendahuluan menghasilkan variabel yang sama persis dengan yang sebelumnya diperoleh dari studi pustaka, yang menunjukkan bahwa variabel dari studi pustaka tersebut adalah relevan bagi responden. Responden juga tidak mencantumkan variabel risiko tambahan pada survei ini.

Terdapat 8 variabel risiko pada aliran material/fisik, 8 variabel risiko pada aliran finansial dan 10 variabel risiko pada aliran informasi.

\subsection{Hasil Survei Utama}

Survei utama dilakukan berdasarkan hasil survei pendahuluan.

1. Data yang didapatkan dari survei utama adalah berupa penilaian persepsi kualitatif probabilitas dan dampak risiko, yaitu dari sudut pandang kontraktor dan dari sudut pandang pemasok, terhadap aktivitas rantai pasok beton ready mix.

2. Menghitung nilai rerata dari persepsi kualitatif probabilitas dan dampak pada masing-masing variabel dari setiap jawaban responden.

Metode yang digunakan untuk menentukan skala probabilitas dan dampak dapat dilihat pada Tabel 3 . Hasil penilaian probabilitas dan dampak risiko dari sudut pandang kontraktor terhadap aktivitas rantai pasok beton ready mix dapat dilihat pada Tabel 4, sedangkan hasil penilaian probabilitas dan dampak risiko dari sudut pandang pemasok terhadap aktivitas rantai pasok beton ready mix dapat dilihat pada Tabel 5.

3. Selanjutnya adalah menyusun Matriks Probabilitas dan Dampak berdasarkan studi pustaka [4], yang kemudian dikustomisasi bersama responden untuk mendapatkan kesepakatan terkait kesesuaian zona kategori risiko terhadap kondisi riil di proyek. Matriks Probabilitas dan Dampak tersebut ditunjukkan oleh Gambar 2. 
Tabel 3. Penentuan Nilai Probabilitas dan Dampak

\begin{tabular}{cc}
\hline $\begin{array}{c}\text { Nilai Rerata } \\
\text { Probabilitas } \\
\text { dan Dampak }\end{array}$ & $\begin{array}{c}\text { Skala Penilaian } \\
\text { Probabilitas dan } \\
\text { Dampak }\end{array}$ \\
\hline $1,00-1,50$ & SR - Sangat Rendah \\
\hline $1,51-2,50$ & R - Rendah \\
\hline $2,51-3,50$ & S - Sedang \\
\hline $3,51-4,50$ & T - Tinggi \\
\hline $4,51-5,00$ & ST - Sangat Tinggi \\
\hline
\end{tabular}

Tabel 4. Hasil Penilaian Persepsi Kontraktor terhadap Aktivitas Rantai Pasok Beton Ready Mix

\begin{tabular}{ccccc}
\hline \multirow{2}{*}{$\begin{array}{c}\text { Kode } \\
\text { Variabel }\end{array}$} & \multicolumn{2}{c}{ Probabilitas } & \multicolumn{2}{c}{ Dampak } \\
\cline { 2 - 5 } & $\begin{array}{c}\text { Rilai } \\
\text { Rerata }\end{array}$ & Skala & $\begin{array}{c}\text { Nilai } \\
\text { Rerata }\end{array}$ & Skala \\
\hline A1 & 1,56 & $\mathrm{R}$ & 1,88 & $\mathrm{R}$ \\
\hline $\mathrm{A} 2$ & 1,50 & $\mathrm{SR}$ & 1,88 & $\mathrm{R}$ \\
\hline $\mathrm{A} 3$ & 3,00 & $\mathrm{~S}$ & 3,81 & $\mathrm{~T}$ \\
\hline $\mathrm{A} 4$ & 3,19 & $\mathrm{~S}$ & 3,56 & $\mathrm{~T}$ \\
\hline $\mathrm{A} 5$ & 2,00 & $\mathrm{R}$ & 2,56 & $\mathrm{~S}$ \\
\hline $\mathrm{A} 6$ & 2,31 & $\mathrm{R}$ & 3,44 & $\mathrm{~S}$ \\
\hline $\mathrm{A} 7$ & 2,00 & $\mathrm{R}$ & 2,63 & $\mathrm{~S}$ \\
\hline $\mathrm{A} 8$ & 1,94 & $\mathrm{R}$ & 2,50 & $\mathrm{R}$ \\
\hline $\mathrm{B} 1$ & 2,31 & $\mathrm{R}$ & 3,44 & $\mathrm{~S}$ \\
\hline $\mathrm{B} 2$ & 2,75 & $\mathrm{~S}$ & 3,50 & $\mathrm{~S}$ \\
\hline $\mathrm{B} 3$ & 2,25 & $\mathrm{R}$ & 3,19 & $\mathrm{~S}$ \\
\hline $\mathrm{B} 4$ & 3,00 & $\mathrm{~S}$ & 3,13 & $\mathrm{~S}$ \\
\hline $\mathrm{B} 5$ & 3,00 & $\mathrm{~S}$ & 4,00 & $\mathrm{~T}$ \\
\hline $\mathrm{B} 6$ & 2,44 & $\mathrm{R}$ & 2,81 & $\mathrm{~S}$ \\
\hline $\mathrm{B} 7$ & 2,50 & $\mathrm{R}$ & 3,00 & $\mathrm{~S}$ \\
\hline $\mathrm{B} 8$ & 1,94 & $\mathrm{R}$ & 3,38 & $\mathrm{~S}$ \\
\hline $\mathrm{C} 1$ & 1,88 & $\mathrm{R}$ & 3,00 & $\mathrm{~S}$ \\
\hline $\mathrm{C} 2$ & 1,81 & $\mathrm{R}$ & 2,38 & $\mathrm{R}$ \\
\hline $\mathrm{C} 3$ & 1,75 & $\mathrm{R}$ & 2,44 & $\mathrm{R}$ \\
\hline $\mathrm{C} 4$ & 2,13 & $\mathrm{R}$ & 2,50 & $\mathrm{R}$ \\
\hline $\mathrm{C} 5$ & 2,75 & $\mathrm{~S}$ & 3,13 & $\mathrm{~S}$ \\
\hline $\mathrm{C} 6$ & 1,88 & $\mathrm{R}$ & 3,06 & $\mathrm{~S}$ \\
\hline $\mathrm{C} 7$ & 2,31 & $\mathrm{R}$ & 2,88 & $\mathrm{~S}$ \\
\hline $\mathrm{C} 8$ & 1,63 & $\mathrm{R}$ & 2,50 & $\mathrm{R}$ \\
\hline $\mathrm{C} 9$ & 1,94 & $\mathrm{R}$ & 2,81 & $\mathrm{~S}$ \\
\hline $\mathrm{C} 10$ & 3,19 & $\mathrm{~S}$ & 2,88 & $\mathrm{~S}$ \\
\hline & & & & \\
\hline
\end{tabular}

Tabel 5. Hasil Penilaian Persepsi Pemasok terhadap Aktivitas Rantai Pasok Beton Ready Mix

\begin{tabular}{ccccc}
\hline \multirow{2}{*}{$\begin{array}{c}\text { Kode } \\
\text { Variabel }\end{array}$} & \multicolumn{2}{c}{ Probabilitas } & \multicolumn{2}{c}{ Dampak } \\
\cline { 2 - 5 } & $\begin{array}{c}\text { Nilai } \\
\text { Rerata }\end{array}$ & Skala & $\begin{array}{c}\text { Nilai } \\
\text { Rerata }\end{array}$ & Skala \\
\hline D1 & 2,14 & $\mathrm{R}$ & 3,14 & $\mathrm{~S}$ \\
\hline $\mathrm{D} 2$ & 1,71 & $\mathrm{R}$ & 3,00 & $\mathrm{~S}$ \\
\hline $\mathrm{D} 3$ & 2,14 & $\mathrm{R}$ & 4,00 & $\mathrm{~T}$ \\
\hline $\mathrm{D} 4$ & 2,14 & $\mathrm{R}$ & 4,00 & $\mathrm{~T}$ \\
\hline $\mathrm{D} 5$ & 2,14 & $\mathrm{R}$ & 3,71 & $\mathrm{~T}$ \\
\hline D6 & 2,14 & $\mathrm{R}$ & 4,29 & $\mathrm{~T}$ \\
\hline D7 & 2,14 & $\mathrm{R}$ & 3,29 & $\mathrm{~S}$ \\
\hline D8 & 2,00 & $\mathrm{R}$ & 4,00 & $\mathrm{~T}$ \\
\hline E1 & 2,43 & $\mathrm{R}$ & 4,29 & $\mathrm{~T}$ \\
\hline E2 & 2,71 & $\mathrm{~S}$ & 3,29 & $\mathrm{~S}$ \\
\hline E3 & 2,43 & $\mathrm{R}$ & 3,43 & $\mathrm{~S}$ \\
\hline & & & &
\end{tabular}

\begin{tabular}{ccccc}
\hline E4 & 2,57 & $\mathrm{~S}$ & 3,00 & $\mathrm{~S}$ \\
\hline E5 & 2,71 & $\mathrm{~S}$ & 3,43 & $\mathrm{~S}$ \\
\hline E6 & 2,57 & $\mathrm{~S}$ & 3,00 & $\mathrm{~S}$ \\
\hline E7 & 2,29 & $\mathrm{R}$ & 3,57 & $\mathrm{~T}$ \\
\hline E8 & 2,43 & $\mathrm{R}$ & 4,43 & $\mathrm{~T}$ \\
\hline $\mathrm{F} 1$ & 2,86 & $\mathrm{~S}$ & 4,00 & $\mathrm{~T}$ \\
\hline F2 & 2,00 & $\mathrm{R}$ & 3,43 & $\mathrm{~S}$ \\
\hline F3 & 2,43 & $\mathrm{R}$ & 3,86 & $\mathrm{~T}$ \\
\hline F4 & 2,43 & $\mathrm{R}$ & 3,86 & $\mathrm{~T}$ \\
\hline F5 & 2,43 & $\mathrm{R}$ & 4,00 & $\mathrm{~T}$ \\
\hline $\mathrm{F} 6$ & 2,14 & $\mathrm{R}$ & 3,57 & $\mathrm{~T}$ \\
\hline $\mathrm{F} 7$ & 2,71 & $\mathrm{~S}$ & 3,14 & $\mathrm{~S}$ \\
\hline $\mathrm{F} 8$ & 2,43 & $\mathrm{R}$ & 2,86 & $\mathrm{~S}$ \\
\hline F9 & 2,43 & $\mathrm{R}$ & 4,14 & $\mathrm{~T}$ \\
\hline F10 & 2,71 & $\mathrm{~S}$ & 4,29 & $\mathrm{~T}$ \\
\hline
\end{tabular}

4. Langkah selanjutnya adalah melakukan pemetaan skala penilaian probabilitas dan dampak ke dalam Matriks Probabilitas dan Dampak.

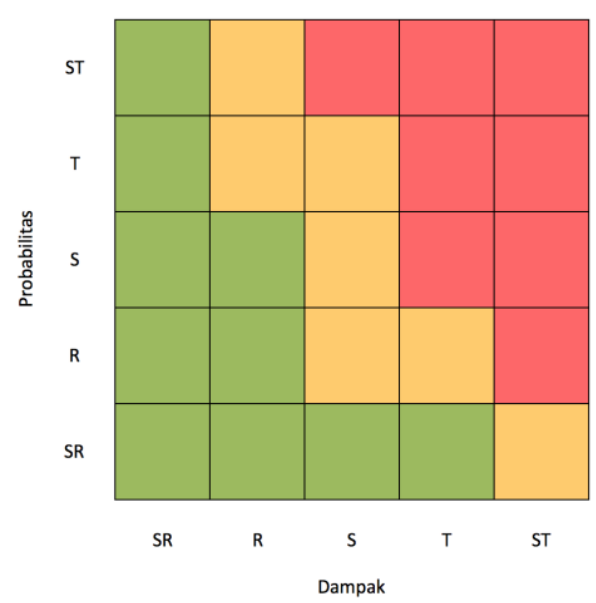

Gambar 2. Matriks Probabilitas dan Dampak

Hasil pemetaan dari sudut pandang kontraktor terhadap aktivitas rantai pasok beton ready mix ditunjukkan oleh Gambar 3, sedangkan hasil pemetaan dari sudut pandang pemasok terhadap aktivitas rantai pasok beton ready mix dapat dilihat pada Gambar 4. 


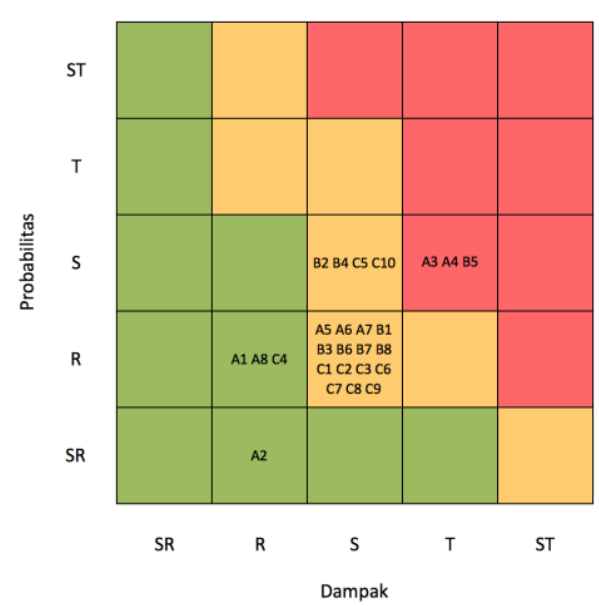

Gambar 3. Hasil Pemetaan Variabel Risiko dari Sudut Pandang Kontraktor terhadap Aktivitas Rantai Pasok Beton

$$
\text { Ready Mix }
$$

Dari matriks pada Gambar 3 dapat diketahui bahwa terdapat 3 variabel risiko kategori tinggi yaitu A3, A4, dan B5.

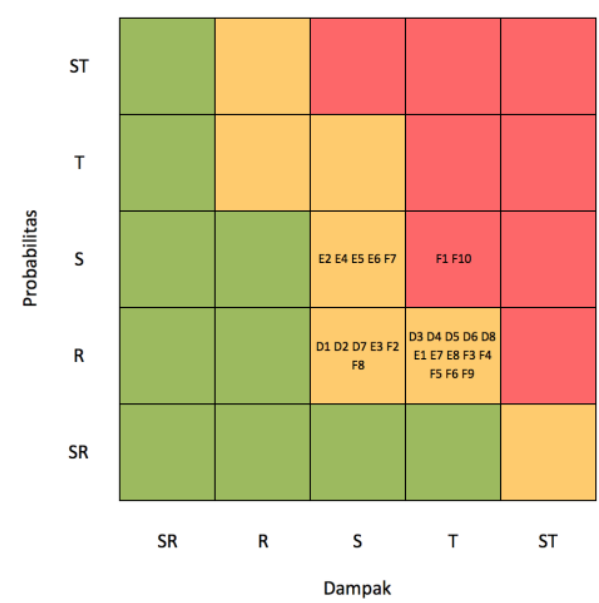

Gambar 4. Hasil Pemetaan Variabel Risiko dari Sudut Pandang Pemasok terhadap Aktivitas Rantai Pasok Beton Ready Mix

Dari matriks pada Gambar 4 dapat diketahui bahwa terdapat 2 variabel risiko kategori tinggi yaitu $\mathrm{F} 1$ dan F10.

\subsection{Hasil Survei Respon Risiko}

Respon risiko pada penelitian ini berupa upaya pencegahan suatu kejadian risiko (strategi risiko preventif) dan upaya penanganan yang dilakukan (strategi risiko kuratif) terhadap faktor penyebab dan dampak risiko tersebut.

Survei respon risiko dilakukan dengan metode wawancara kepada responden, terhadap risiko berkategori tinggi.

1. Respon Risiko oleh Kontraktor terhadap Aktivitas Rantai Pasok Beton Ready Mix.

Hasil survei respon risiko oleh kontraktor terhadap aktivitas rantai pasok beton ready mix disajikan pada Tabel 6.

Tabel 6. Hasil Survei Respon Risiko oleh Kontraktor terhadap Aktivitas Rantai Pasok Beton Ready Mix

\begin{tabular}{|c|c|}
\hline \multicolumn{2}{|c|}{$\begin{array}{c}\text { Variabel A3 } \\
\begin{array}{c}\text { Ketidakstabilan pasokan material oleh pemasok } \\
\text { kepada kontraktor }\end{array}\end{array}$} \\
\hline $\begin{array}{l}\text { Faktor } \\
\text { Penyebab }\end{array}$ & $\begin{array}{l}\text { - } \\
\text { Pemasok mengalami } \\
\text { kelangkaan bahan baku yang } \\
\text { disebabkan peraturan daerah } \\
\text { terkait pembatasan ijin } \\
\text { penambangan pasir } \\
\text { - } \\
\text { Pemasok kekurangan armada } \\
\text { untuk mengangkut beton ready } \\
\text { mix ke lokasi proyek }\end{array}$ \\
\hline Dampak & $\begin{array}{ll}- & \text { Kontraktor mengalami } \\
\text { keterlambatan kinerja terhadap } \\
\text { jadwal yang telah ditentukan } \\
\text { - } \\
\text { Kontraktor mengeluarkan } \\
\text { tambahan biaya upah pekerja } \\
\text { akibat penambahan jam kerja }\end{array}$ \\
\hline $\begin{array}{l}\text { Strategi } \\
\text { Risiko } \\
\text { Preventif }\end{array}$ & 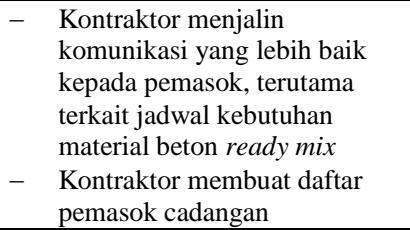 \\
\hline $\begin{array}{l}\text { Strategi } \\
\text { Risiko } \\
\text { Kuratif }\end{array}$ & $\begin{array}{l}\text { Kontraktor mencari pemasok lain } \\
\text { untuk dapat memenuhi kebutuhan } \\
\text { beton ready mix }\end{array}$ \\
\hline \multicolumn{2}{|c|}{$\begin{array}{c}\text { Variabel A4 } \\
\text { Keterlambatan pengiriman material oleh } \\
\text { pemasok kepada kontraktor yang diakibatkan } \\
\text { proses mendapatkan material pengganti }\end{array}$} \\
\hline $\begin{array}{l}\text { Faktor } \\
\text { Penyebab }\end{array}$ & $\begin{array}{l}\text { Pemasok mengalami kelangkaan } \\
\text { bahan baku yang disebabkan } \\
\text { peraturan daerah terkait pembatasan } \\
\text { ijin penambangan pasir }\end{array}$ \\
\hline Dampak & $\begin{array}{l}\text { Kontraktor mengalami } \\
\text { keterlambatan kinerja terhadap } \\
\text { jadwal yang telah ditentukan }\end{array}$ \\
\hline $\begin{array}{l}\text { Strategi } \\
\text { Risiko } \\
\text { Preventif }\end{array}$ & $\begin{array}{l}\text { Kontraktor menjalin } \\
\text { komunikasi yang lebih baik } \\
\text { kepada pemasok }\end{array}$ \\
\hline
\end{tabular}




\section{ISSN.1907-753X}

\begin{tabular}{|c|c|}
\hline & $\begin{array}{l}\text { - } \begin{array}{l}\text { Kontraktor membuat daftar } \\
\text { pemasok cadangan }\end{array} \\
\end{array}$ \\
\hline $\begin{array}{l}\text { Strategi } \\
\text { Risiko } \\
\text { Kuratif }\end{array}$ & $\begin{array}{l}\text { Kontraktor mencari pemasok lain } \\
\text { untuk dapat memenuhi kebutuhan } \\
\text { beton ready mix }\end{array}$ \\
\hline \multicolumn{2}{|c|}{$\begin{array}{c}\text { Variabel B5 } \\
\text { Perubahan harga material yang dipasok }\end{array}$} \\
\hline $\begin{array}{l}\text { Faktor } \\
\text { Penyebab }\end{array}$ & $\begin{array}{l}\text { Pemasok memasukkan unsur } \\
\text { perubahan tarif BBM, TDL, UMR, } \\
\text { dan harga bahan baku beton ready } \\
\text { mix ke dalam harga jual terbaru }\end{array}$ \\
\hline Dampak & $\begin{array}{l}\text { Anggaran kontraktor menjadi tidak } \\
\text { akurat atau bahkan defisit }\end{array}$ \\
\hline $\begin{array}{l}\text { Strategi } \\
\text { Risiko } \\
\text { Preventif }\end{array}$ & $\begin{array}{l}\text { Kontraktor memasukkan risiko } \\
\text { perubahan harga dalam penyusunan } \\
\text { estimasi biaya untuk beton ready } \\
\text { mix }\end{array}$ \\
\hline $\begin{array}{l}\text { Strategi } \\
\text { Risiko } \\
\text { Kuratif }\end{array}$ & $\begin{array}{l}\text { Kontraktor melakukan negosiasi } \\
\text { kepada pemasok agar perubahan } \\
\text { harga yang diberikan tidak terlalu } \\
\text { signifikan }\end{array}$ \\
\hline
\end{tabular}

2. Respon Risiko oleh Pemasok terhadap Aktivitas Rantai Pasok Beton Ready Mix.

Hasil survei respon risiko oleh pemasok terhadap aktivitas rantai pasok beton ready mix disajikan pada Tabel 7.

Tabel 7. Hasil Survei Respon Risiko oleh Pemasok terhadap Aktivitas Rantai Pasok Beton Ready Mix

\begin{tabular}{|c|c|}
\hline \multicolumn{2}{|c|}{$\begin{array}{c}\text { Variabel F1 } \\
\begin{array}{c}\text { Ketidakjelasan kontraktor dalam memberikan } \\
\text { informasi }\end{array}\end{array}$} \\
\hline $\begin{array}{l}\text { Faktor } \\
\text { Penyebab }\end{array}$ & $\begin{array}{ll}- & \text { Kontraktor belum memberikan } \\
\text { jadwal pengecoran yang akurat } \\
-\quad \text { Kontraktor terlambat dalam } \\
\text { menyiapkan lokasi/zona } \\
\text { pengecoran di lokasi proyek }\end{array}$ \\
\hline Dampak & $\begin{array}{l}\text { Pemasok mengalami kerugian } \\
\text { berupa bertambahnya waktu dan } \\
\text { biaya untuk menunggu dan } \\
\text { mempertahankan mutu material }\end{array}$ \\
\hline $\begin{array}{l}\text { Strategi } \\
\text { Risiko } \\
\text { Preventif }\end{array}$ & $\begin{array}{l}\text { Pemasok melakukan komunikasi } \\
\text { kepada kontraktor untuk } \\
\text { memastikan jadwal pengecoran dan } \\
\text { kesiapan lokasi/zona pengecoran }\end{array}$ \\
\hline $\begin{array}{l}\text { Strategi } \\
\text { Risiko } \\
\text { Kuratif }\end{array}$ & $\begin{array}{l}\text { Pemasok mencari proyek lain untuk } \\
\text { mengalihkan pasokan beton ready } \\
\text { mix yang sudah terlanjur tersedia }\end{array}$ \\
\hline \multicolumn{2}{|c|}{$\begin{array}{c}\text { Variabel F10 } \\
\text { Minimnya frekuensi rapat koordinasi antara } \\
\text { pihak yang terlibat dalam proses konstruksi }\end{array}$} \\
\hline $\begin{array}{l}\text { Faktor } \\
\text { Penyebab }\end{array}$ & 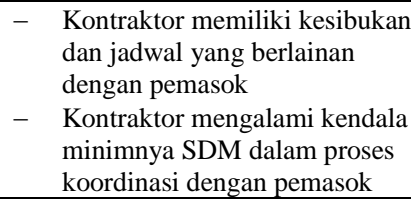 \\
\hline Dampak & $\begin{array}{l}\text { Pemasok berpotensi } \\
\text { mengalaminya terjadinya } \\
\text { kesalahan pertukaran informasi }\end{array}$ \\
\hline
\end{tabular}

\begin{tabular}{ll}
\hline & $\begin{array}{l}\text { Pemasok berpotensi menerima } \\
\text { komplain dari kontraktor atas } \\
\text { ketidakpuasan beton ready mix } \\
\text { yang dipasok }\end{array}$ \\
\hline $\begin{array}{l}\text { Strategi } \\
\text { Risiko } \\
\text { Preventif }\end{array}$ & $\begin{array}{l}\text { Pemasok melakukan inisiatif untuk } \\
\text { melakukan komunikasi dan } \\
\text { koordinasi secara intensif kepada } \\
\text { kontraktor }\end{array}$ \\
\hline Strategi & $\begin{array}{l}\text { Pemasok menugaskan petugas } \\
\text { Risiko } \\
\text { Kuratif }\end{array}$ \\
& $\begin{array}{l}\text { kepangan untuk memberi informasi } \\
\text { permasalahan dalam proses }\end{array}$ \\
& pemesanan, pengiriman, dan \\
& pengecoran di lapangan
\end{tabular}

\section{Simpulan}

Berdasarkan hasil analisa dan pembahasan, dapat disimpulkan sebagai berikut:

1. Terdapat 8 variabel risiko pada aliran material/fisik, 8 variabel risiko pada aliran finansial, dan 10 variabel risiko pada aliran informasi yang relevan terkait risiko rantai pasok pada proyek pembangunan apartemen di Surabaya.

2. Berdasarkan hasil survei utama dan analisis data, didapatkan risiko kategori tinggi sebagai berikut:

a. Risiko kategori tinggi dari sudut pandang kontraktor terhadap aktivitas rantai pasok beton ready mix adalah ketidakstabilan pasokan material oleh pemasok kepada kontraktor; keterlambatan pengiriman material oleh pemasok kepada kontraktor yang diakibatkan proses mendapatkan material pengganti; dan perubahan harga material yang dipasok.

b. Risiko kategori tinggi dari sudut pandang pemasok terhadap aktivitas rantai pasok beton ready mix adalah, ketidakjelasan kontraktor dalam memberikan informasi; dan minimnya frekuensi rapat koordinasi antara pihak yang terlibat dalam proses konstruksi. 
3. Respon terhadap risiko kategori tinggi yang dilakukan adalah:

a. Respon risiko yang dilakukan kontraktor dalam menanggulangi risiko ketidakstabilan pasokan material oleh pemasok kepada kontraktor dan keterlambatan pengiriman material oleh pemasok kepada kontraktor yang diakibatkan proses mendapatkan material pengganti adalah kontraktor mencari pemasok lain untuk dapat memenuhi kebutuhan beton ready mix di proyek. Sedangkan upaya penanganan yang dilakukan pada risiko perubahan harga material yang dipasok adalah kontraktor melakukan negosiasi kepada pemasok agar perubahan harga yang diberikan tidak terlalu signifikan.

b. Respon risiko yang dilakukan pemasok beton ready mix dalam mengatasi risiko ketidakjelasan kontraktor dalam memberikan informasi adalah pemasok mencari proyek lain untuk mengalihkan pasokan beton ready mix yang sudah terlanjur tersedia. Sedangkan strategi untuk menangani risiko minimnya frekuensi rapat koordinasi antara pihak yang terlibat dalam proses konstruksi adalah pemasok menugaskan petugas lapangan untuk memberi informasi kepada kontraktor apabila terjadi permasalahan dalam proses pemesanan, pengiriman, dan pengecoran di lapangan.

\section{Daftar Pustaka}

Baskoro, B.B., 2013. Analisis Risiko pada Proyek Fly-Over Pasar Kembang - Surabaya, Tugas Akhir Program Sarjana Teknik Sipil ITS, Surabaya.

Belliawan, A., 2011. Analisa Risiko Konstruksi pada Proyek Trillium Office and Residence - Surabaya, Tugas Akhir Program Sarjana Teknik Sipil ITS, Surabaya.

Nugroho, B., 2011. Studi Pengambilan Keputusan Investasi dengan Risiko pada Proyek Trillium Office and Residence - Surabaya, Tugas Akhir Program Sarjana Teknik Sipil ITS, Surabaya.

Project Management Institute, 2013. A Guide to the Project Management Body of Knowledge (PMBOK Guide), Project Management Institute, Inc. Pennsylvania, USA.

Pujawan, I N., 2005. Supply Chain Management, Edisi Pertama, Guna Widya, Surabaya.

Soepiadhy, S., 2011. Pengaruh Rantai Pasok terhadap Kinerja Kontraktor Bangunan Gedung di Jember, Tesis Magister, Program Studi Pascasarjana Teknik Sipil ITS, Surabaya.

Soetowijoyo, H., 2011. Penilaian Persepsi Risiko Rantai Pasok pada Proyek Konstruksi Gedung di Surabaya, Tesis Magister, Program Studi Pascasarjana Teknik Sipil ITS, Surabaya. 